\title{
Geochemistry of Spinel \pm Garnet Lherzolite Xenoliths from Pali Aike: Implications for Evolution of Mantle Lithosphere beneath Southern Patagonia
}

\author{
Kempton, P.D. ${ }^{1}$, Hawkesworth, C.J. ${ }^{2}$, Lopez-Escobar, L. ${ }^{3}$, and Ware, A.J. ${ }^{2}$ \\ 1. NERC Isotope Geosciences Laboratory, Kingsley Dunham Centre, Keyworth, UK, NG12 5GG \\ 2. The Open University, Milton Keynes, UK, MK7 6AA \\ 3. Instituto GEA, Universidad de Concepcion, Casilla 4107, Concepcion 3, Chile
}

\section{Introduction}

The Pali Aike volcanic field is the southernmost outcrop of mantle-xenolith-bearing, PlioQuaternary alkali-basalts that occur east of the Andes from northern Argentina to southern Patagonia. It covers an area of approximately $150 \mathrm{~km}^{2}$, straddling the Chile-Argentina border at the southernmost tip of South America, and is situated on a Phanerozoic accretionary terrain that is presently an area of back-arc magmatism. The xenoliths, thus, provide important information about the nature of the sub-Andean lithospheric mantle. Pali Aike is also the only locality so far known in South America that contains garnet-, spinel- and spinel \pm garnet facies mantle peridotite xenoliths in the same suite. Type I ( $\mathrm{Cr}$ diopside-bearing) clinopyroxene (cpx) depleted lherzolites and harzburgites predominate, whereas garnet (gar) and spinel (sp) + gar lherzolites make up less than $10 \%$ of the recovered samples. Type II (Al-augite) nodules and composite xenoliths are rare.

Pressures and temperatures of equilibration for garnet-bearing peridotites (calculated using Brey and Kohler, 1990) range from 12 to $24 \mathrm{~kb}$ and 840 to $1090^{\circ} \mathrm{C}$, respectively. Spinel lherzolite temperatures (calculated using Wood and Banno, 1973) show a wider range $\left(900-1234^{\circ} \mathrm{C}\right.$ ) and extend to significantly higher $\mathrm{T}$ than the garnet-bearing peridotites. However, Wood and Banno yields consistently higher temperatures than Brey and Kohler for the garnet-bearing samples, with the discrepancy greatest at lower pressures $\left(\Delta=153^{\circ} \mathrm{C}\right.$ at $12 \mathrm{~kb}$ and $0^{\circ} \mathrm{C}$ at $\left.24 \mathrm{~kb}\right)$. Thus, calculated temperatures for spinel lherzolites are probably $\sim 100^{\circ}$ too high. If so, the temperature ranges for the different peridotite types largely overlap, suggesting that the spinel, garnet and $\mathrm{sp} \pm$ gar lherzolites occur over the same depth range in the mantle.

\section{Geochemical Results}

Olivines from most Pali Aike xenoliths are $\mathrm{Mg}$-rich, with high $\mathrm{Mg}$ numbers of Fo 90 to $92 . \mathrm{Al}_{2} \mathrm{O}_{3}$ contents of $\mathrm{Cr}$ diopsides from Pali Aike spinel lherzolites are low and $\mathrm{Cr}_{2} \mathrm{O}_{3}$ contents high when compared with normal Type Ia (LREE-depleted) spinel lherzolites worldwide, but they overlap the fields for low-Al harzburgites and Type Ib (LREE-enriched) spinel lherzolites worldwide; they also overlap the field of garnet lherzolites from South Africa (Fig. 1). In contrast, diopsides from Pali Aike gar $\pm \mathrm{sp}$ lherzolites have higher $\mathrm{Al}_{2} \mathrm{O}_{3}$ contents than Pali Aike spinel lherzolites; but lower concentrations than in cpx from gar \pm sp peridotites from Mongolia (Ionov et al., 1993) and SE China (Fan and Hooper, 1989). These data suggest that Pali Aike spinel lherzolites have undergone a greater degree of depletion via melt extraction than (a) Pali Aike gar \pm sp lherzolites, and (b) most spinel lherzolites world wide (Fig. 1). Similarly, the Pali Aike gar \pm sp lherzolites appear to be more depleted than gar $\pm \mathrm{sp}$ lherzolites from Mongolia and China, although garnet lherzolites from South Africa are significantly more depleted than the $\mathrm{sp} \pm$ gar-bearing xenolith localities from these younger cratonic regions.

In situ trace element determinations of $\mathrm{Ba}, \mathrm{Nb}, \mathrm{Zr}, \mathrm{Y}, \mathrm{Sr}, \mathrm{Ti}$ and the $\mathrm{REE}$ were made using the ion microprobe at Edinburgh University. Garnets have typical LREE-depleted chondrite-normalized 


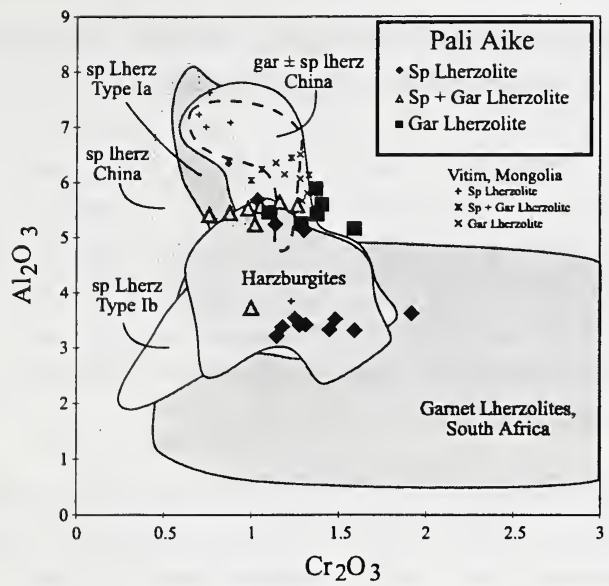

Figure 1. Plot of $\mathrm{Al}_{2} \mathrm{O}_{3}$ vs. $\mathrm{Cr}_{2} \mathrm{O}_{3}$ in cpx. Data for China from Fan and Hooper (1989); Mongolia from Ionov et al. (1993).

profiles. Extended trace element plots show a similar depletion of LILE, but variable depletions of $\mathrm{Ti}$; in contrast, there are relative enrichments in $\mathrm{Nb}$ and, in some cases, Y and Zr. Clinopyroxene from both garbearing and garnet-free lherzolites have unusual concave downward REE patterns, with maxima in the middle rare earths, more typical of cumulate Type II pyroxenes than Type I Cr-diopsides. $\mathrm{Zr}$ shows very small depletions in most samples, but unlike the data of Salters and Shimizu (1988), only one sample shows a significant Ti depletion. Importantly, there is no clear $\mathrm{Nb}$ depletion relative to adjacent trace elements in the diagram. Amphibole shows similar chondritenormalized REE patterns to clinpyroxene, but extended trace element plots are unusual in that they have two peaks, one at $\mathrm{Nb}$ and one at $\mathrm{Ti}$, indicating that the HFSE are enriched relative to REE in this phase. The cpx data reflect equilibration with garnet, even in samples where garnet is not present, possibly via interaction with migrating silicate melts generated in equilibrium with garnet. However, petrographic evidence for metasomatism of the xenoliths (e.g. secondary amphibole, mica or pyroxene) is rare, which contrasts with the clearly metasomatised mantle xenoliths from Andean localities further north (Killian and Altherr, 1997). Nonetheless, small enrichments of REE in cpx rims relative to cores is indicative of fluid-rock interaction during metasomatism.

\section{HFSE in the Mantle}

Depletion of the HFSE relative to the REE is considered one of the most diagnostic geochemical features of island arc magmas, yet the fact that depletions in $\mathrm{Ti}$ and $\mathrm{Zr}$ are observed for a variety of peridotite samples (Salters and Shimizu, 1988; Johnson et al., 1990) suggest that this is common in the shallow lithospheric mantle, even away from the arc environment.

Nevertheless, cpx from most continental spinel lherzolite xenoliths and massifs cluster around the chondritic mantle $\mathrm{Ti} / \mathrm{Zr}$ ratio of 100 (Fig. 2). Simple model calculations of partial melting suggest that the residua left after melting should have higher $\mathrm{Ti} / \mathrm{Zr}$ than the original material. Consistent with this, abyssal peridotites show increasing $\mathrm{Ti} / \mathrm{Zr}$ with decreasing trace element concentration in cpx, as does cpx from many continental spinel lherzolites and from deformed garnet peridotites. This trend has been modelled by Johnson et al. (1990) by repeated melting and segregation of $\leq 0.1 \%$ melt increments (totaling from 5 to $25 \%$ melting) of a LREE-depleted source.

By contrast, although garnets from South African peridotites and $\mathrm{sp} \pm$ gar lherzolites from Pali Aike overlap this ratio, they extend to lower rather than higher Ti/Zr. Within the array of South African samples, most deformed garnet peridotites plot near the $\mathrm{Ti} / \mathrm{Zr}=100$ line, while coarse granular peridotites (cpx and garnet) plot below and to the right (Fig. 2). Although Ti/Zr ratios for Pali Aike mineral phases range from 120 to 2 , no correlation with degree of depletion has been established.

It thus seems unlikely that the garnet lherzolite compositions can be derived from chondritic mantle materials by partial melting processes alone. It is also difficult to reconcile these data with a metasomatic model involving silicate melts since this hypothesis requires mixing a high $\mathrm{Ti} / \mathrm{Zr}$ (>100) residua with a melt of anomalously low Ti/Zr; MORB, OIB, and Pali Aike alkali basalts 


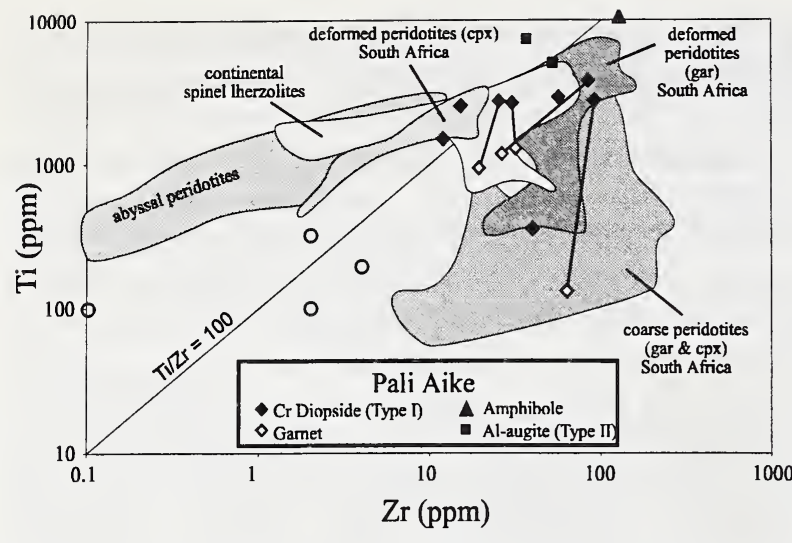

Figure 2. Plot of $\mathrm{Zr}$ vs. Ti comparing Pali Aike peridotite minerals to abyssal peridotite cpx, continental sp lherzolite cpx worldwide and garnet lherzolite (cpx and garnet) from South Africa. Open circles indicate unusual cpx compositions from Lunar Crater, USA (Roden and Shimizu, 1993). have average $\mathrm{Ti} / \mathrm{Zr}$ ratios of $\sim 100,60$, and 80 , respectively). Equilibration with, or fractionation of, ilmentite may play a role in producing these trends in the South African xenoliths since they commonly contain this phase. However, traces of ilmenite have only been found in the Pali Aike clinopyroxenites and wehrlites, not in the lherzolites, and these samples have near. chondritic $\mathrm{Ti} / \mathrm{Zr}$ ratios (Fig. 2).

Furthermore, HFSE distributions in cpx and garnet from Pali Aike xenoliths are inconsistent with experimentally determined D-values. At equilibrium, garnet should have higher $\mathrm{Ti}$ and $\mathrm{Zr}$ contents than coexisting cpx. Most South African peridotites display this relationship, even

those with low $\mathrm{Ti} / \mathrm{Zr}$ ratios, but Pali Aike cpxs have significantly higher Ti contents than coexisting garnet, and generally higher $\mathrm{Ti} / \mathrm{Zr}$ ratios. Based on experimental data involving silicate melts, the ratio of $\mathrm{Zr}^{\text {gar }} / \mathrm{Zr}^{\mathrm{cpx}}$ should be approximately $7\left(\mathrm{D}_{\mathrm{Zar}}^{\mathrm{Zr}}=0.6-0.7 ; \mathrm{D}^{\mathrm{Zr}}{ }_{\mathrm{cpx}}=0.1\right.$; Green et al., 1989). Many garnet lherzolites from South Africa plot near this equilibrium ratio, although others extend away to lower $\mathrm{Zr}^{\mathrm{gar}} / \mathrm{Zr}^{\mathrm{cpx}}$. All Pali Aike samples have significantly lower $\mathrm{Zr}^{\mathrm{gar}} / \mathrm{Zr}^{\mathrm{cpx}}$ values than expected at equilibrium $\left(\mathrm{Zr}^{\mathrm{gar}} / \mathrm{Zr}^{\mathrm{cpx}}=1.0-0.2\right)$. Even if one invokes carbonatite metasomatism $\left(D^{Z r}{ }_{\text {gar }}=0.8-1.4 ; D^{Z} r_{c p x}=0.29\right.$; Sweeney et al., 1995), the ratio of $\mathrm{Zr}^{\text {gar }} / \mathrm{Zr}^{\mathrm{cpx}}$ would still be too high (3 - 5). These results suggest that HFSE systematics in Pali Aike peridotite phases are a function of mineralogical disequilibrium. The spinel $\rightarrow$ garnet $\rightarrow$ spinel reaction textures preserved in these samples are a visible testimony that chemical equilibrium has not been attained, at least in the $\mathrm{sp} \pm$ gar assemblages. Thus unusual trace element signatures are preserved in some samples.

\section{References}

Brey, G. and Kohler, T., 1990, Geothermobarometry in four-pphase lherzolites. II. New thermobarometers and practical assessment of existing thermobarometers: J. Petrol. v. 31, 1353-1378.

Fan, Q. and Hooper, P.R., 1989, The mineral chemistry of ultramafic xenoliths of eastern China: implications for upper mantle composition and the paleogeotherms: J. Petrol., v. 30, p. 1117-1158.

Green, T.H., Sie, S.H., Ryan, C.G., and Cousens, D.R., Proton microprobe-determined partitioning of Nb, Ta, Zr, Sr and Y between garnet, cpx and basaltic magma at high pressure and temperature: Chem. Geol., v. 74, p. 201-216.

Ionov, D.A., Ashchepkov, I.V., Stosch, H-G., Witt-Eickschen, G., and Seck, H.A., 1993, Garnet peridotite xenoliths from the Vitim volcanic field, Baikal region: J. Petrol. v. 34, p. 1141-1175.

Johnson, K..T.M., Dick, H.J.B. and Shimizu, N., 1990, Melting in the oceanic upper mantle: an ion microprobe study of diopsides in abyssal peridotites: J. Geophys. Res., v. 95, p. 2661-2678.

Killian, R. and Altherr, R. (1997) Metasomatic processes in the mantle wedge: constraints from mantle xenoliths of the southern Andes ( $50^{\circ}$ S). Terra Nova (Abstract Supplement \#1), v. 9, p. 471.

Roden, M.F. and Shimizu, N., 1993, Ion microprobe analyses bearing on the composition of the upper mantle beneath the Basin and Range and Colorado Plateau provinces: J. Geophys. Res., v. 98, p. 14091-14108.

Salters, V.J.M. and Shimizu, N., 1988, World-wide occurrence of HFSE-depleted mantle, Geochim. Cosmochim. Acta, v. 52 , p. $2177-2182$.

Sweeney, R.J., Prozesky, V. and Przybylowicz, W., 1995, Selected trace and minor element partitioning between peridotite minerals and carbonatite melts at 18-46 kb pressure, Geochim. Et Cosmochim. Acta, v. 59, p..3671-3683. 